Jenius: Jurnal of Education Policy and Elementary Education Issues

Vol.1, No.2, Desember 2020, pp. 63-73

\title{
PENERAPAN TOTAL QUALITY MANAGEMENT (TQM) SEBAGAI UPAYA MENINGKATKAN KINERJA GURU DALAM PEMBELAJARAN
}

\author{
Muhammad Maksum \\ SD Negeri Panohan, Kec. Gunem, Kab. Rembang \\ E-mail: maksummuhammad@gmail.com
}

\begin{abstract}
The low performance of teachers in learning will have an impact on the quality of education in schools, so an effort is needed to improve teacher performance. The purpose of this study was to analyze the improvement of teacher performance in learning in elementary schools through the application of Total Quality Management (TQM). This research is School Action Research (PTS). The time of this research is Semester I of the 2019/2020 Academic Year. The place of this research is Panohan Elementary School, Gunem District, Rembang Regency. The subjects of this study were six teachers. Data collection techniques with non-test, namely observation of the subject. Data analysis technique with comparative descriptive and qualitative descriptive. The results of this study are the application of Total Quality Management (TQM) to improve the performance of SD Negeri Panohan teachers in learning, from the planning aspect from the average value of 55 (enough category) to an average value of 79 (high category), and the implementation of learning from an average score of 56 (enough category) to an average value of 84 (very high category). The results of this study are expected to be used as an alternative for school principals to improve teacher performance and education quality.
\end{abstract}

Keywords: Primary School; Teacher Performance; Total Quality Management (TQM)

Abstrak Rendahnya kinerja guru dalam pembelajaran akan berdampak pada mutu pendidikan di sekolah, sehingga dibutuhkan suatu upaya untuk dapat meningkatkan kinerja guru. Tujuan dari penelitian ini adalah untuk menganalisis peningkatan kinerja guru dalam pembelajaran di sekolah dasar melalui penerapan Total Quality Management (TQM). Penelitian ini merupakan Penelitian Tindakan Sekolah (PTS). Waktu penelitian ini adalah Semester I Tahun Pelajaran 2019/2020. Tempat penelitian ini adalah SD Negeri Panohan, Kecamatan Gunem, Kabupaten Rembang. Subyek penelitian ini adalah enam orang guru. Teknik pengumpulan data dengan non tes, yaitu pengamatan terhadap subyek. Teknik analisis data dengan deskriptif komparatif dan deskriptif kualitatif. Hasil penelitian ini adalah penerapan Total Quality Management (TQM) meningkatkan kinerja guru SD Negeri Panohan dalam pembelajaran, dari aspek perencanaan dari nilai rata-rata sebesar 55 (kategori cukup) menjadi nilai rata-rata sebesar 79 (kategori tinggi), dan pelaksanaan pembelajaran dari nilai rata-rata sebesar 56 (kategori cukup) menjadi nilai rata-rata sebesar 84 (kategori sangat tinggi). Hasil dari penelitian ini diharapkan dapat dijadikan alternatif bagi Kepala Sekolah untuk meningkatkan kinerja guru dan mutu pendidikan.

Kata Kunci : Kinerja Guru; Sekolah Dasar; Total Quality Management (TQM) 


\section{PENDAHULUAN}

Keberhasilan tujuan pendidikan tidak dapat dilepaskan dari peran serta beberapa komponen pendukung, diantaranya sarana penunjang. Beberapa sarana penunjang dalam sistem pendidikan kita adalah kurikulum, tenaga kependidikan, pengelolaan, dan sumber daya pendidikan. Guru merupakan salah satu sumber daya pendidikan yang memiliki peran penting dalam mencapai keberhasilan tujuan pendidikan. Menurut Djamarah (2000: 31), guru adalah orang yang memberikan ilmu pengetahuan kepada anak didik, sehingga untuk menghasilkan atau mencetak anak didik yang berkualitas, maka guru harus memiliki kinerja yang berkualitas pula.

Kinerja guru berkaitan dengan tugas perencanaan, pengelolalan pembelajaran dan penilaian hasil belajar peserta didik. Menurut Handayani (2014) faktror yang mempengaruhi kinerja guru diantaranya keterampilan guru dalam mengelola kelas, terutama dalam berkomunikasi dengan peserta didik, kemampuan dalam merancang pembelajaran sesuai standart kurikulum nasional dan kondisi lapangan, penguasaan terhadap materi pelajaran, menguasai metode dan strategi pembelajaran, motivasi dalam menagajar dalam meningkatkan prestasi peserta didik, penguasaan kompetensi yang harus dicapai peserta didik, keterampilan mengajar, dan keterampilan dalam mengevaluasi pembelajaran. Keterampilan guru dalam mengajar akan berpengaruh pada motivasi dan hasil belajar siswa (Safitri \& Sontani, 2016), serta keberhasilan proses belajar di kelas (Saragih, 2008).

Berdasarkan hasil observasi kelas terhadap kinerja guru di SD Negeri Panohan, kinerja guru dalam merancang pembelajaran masih kurang inovatif, sedangkan pelaksanaan pembelajaran masih tidak sesuai dengan rancangan pembelajaran dan guru kurang terampil dalam mengajar. Kondisi ini sangat berpengaruh terhadap mutu pendidikan di SD Negeri Panohan, diantaranya daya serap peserta didik dalam pembelajaran rendah, nilai lulusan rendah dan tidak pernah mendapatkan prestasi ketika ada lomba-lomba, baik akademik maupun non akademik. Berdasarkan pengamatan Kepala Sekolah, hal ini disebabkan oleh beberapa faktor, antara lain beberapa guru sudah mendekati masa pensiun, sehingga kinerjanya mulai menurun dan beberapa guru lainnya masih berstatus Guru Tidak Tetap (GTT) yang belum memiliki pengalaman mengajar yang memadai dan jarang mendapatkan pelatihan untuk meningkatkan kompetensinya.

Menurut Hasanah (2015) dampak dari rendahnya kompetensi guru akan berdampak pada kurang optimalnya pembelajaran, pembelajaran menjadi kurang efektif dan tidak efisien, pembelajaran kurang inovatif, dinamis dan produktif. Sehingga dibibutuhkan suatu strategi untuk dapat meningkatkan kinerja guru. Suponco (2018) dan dan Baridin (2018) menjelaskan kurangnya 
Jenius: Jurnal of Education Policy and Elementary Education Issues

Vol.1, No.2, Desember 2020, pp. 63-73

kompetensi aan berdampak pada mutu pendidikan. selain kompetensi atau kinerja guru, kepemimpinan kepala sekolah juga mempengaruhi mutu pendidikna (Suponco, 2018; Susanto \& Mattalatta, 2018), sehingga kepala sekolah harus inovatif dalam mencari stratgei untuk dapat meningkatkan kinerja guru.

Berdasarkan penelitian Masturi, Ramdani \& Muntari (2017) strategi yang dapat meningkatkan kinerja guru adalah Total Quality Management (TQM). Kinerja guru yang meningkat, maka akan berpengaruh pada mutu pendidikan. Penelitian Azizah \& Witri (2021) dan Indana (2017) menunjukkan TQM mampu meningkatkan mutu pendidikan, sedangka menurut Dewi \& Primayana (2019) TQM merupakan suatu manajemen yang mampu menggerakkan organisasi sekolah, dan menciptakan lingkungan belajar yang kondusif dan berkelanjutan. Menurut Syafaruddin (2002: 36), TQM pendidikan merupakan strategi manajemen mutu yang disesuaikan dengan sifat dasar sekolah sebagai organisasi jasa kemanusiaan (pembinaan potensi pelajar) melalui pengembangan pembelajaran berkualitas agar melahirkan lulusan yang sesuai dengan harapan orang tua, masyarakat dan pelanggan pendidikan lainnya. Tujuan utama dari TQM pendidikan, yaitu meningkatkan mutu pendidikan melalui peningkatan di segala komponen pendidikan secara berkelanjutan dan bertahap (Azizah \& Witri, 2021). Prinsip untuk mencapai tujuan tersebut adalah fokus pada pelanggan, peningkatan kualitas melalui proses serta melibatkan seluruh tim yang ada secara menyeluruh. Agar implementasi TQM di bidang pendidikan berhasil harus didukung dengan adanya peningkatan kualitas pendidikan secara berkelanjutan melalui: kepemimpinan, pendidikan dan latihan, dukungan struktur, komunikasi, penghargaan dan pengakuan serta pengukuran. Menurut (Zazin, 2011) TQM dapat mengembangkan program melaui perencanaan yang nantinya mampu menunjukkan keunggulan bagi satuan pendidikan. Berdasarkan latar belakang, maka peneliti tertarik untuk menganalisis penerapan TQM dalam meningkatkan kinerja guru.

\section{METODE}

Penelitian ini merupakan Penelitian Tindakan Sekolah (PTS). Tindakan dalam penelitian ini adalah penerapan Total Quality Management (TQM/Manajemen Kualitas Total). Penelitian ini berlangsung dalam 2 siklus, yaitu Siklus I dan Siklus II. Tindakan pada Siklus I adalah sosialisasi dan diskusi tentang TQM. Sedangkan tindakan pada Siklus II adalah bimbingan sesuai dengan TQM. Waktu penelitian ini pada Semester I Tahun Pelajaran 2019/2020, tepatnya bulan Agustus sampai November tahun 2019. Tempat penelitian ini adalah SD Negeri Panohan, Kecamatan 
Jenius: Jurnal of Education Policy and Elementary Education Issues

Vol.1, No.2, Desember 2020, pp. 63-73

Gunem, Kabupaten Rembang. Tempat penelitian merupakan unit kerja dari penulis sebagai Kepala Sekolah. Subjek penelitian ini adalah Guru Kelas sebanyak 6 orang terdiri dari 3 laki-laki dan 3 perempuan. Subjek penelitian berstatus sebagai Guru PNS maupun GTT. Subjek penelitian secara lengkap sebagai berikut:

Tabel 1. Subjek Penelitian.

\begin{tabular}{cccc}
\hline No & Tugas & Status & Kode \\
\hline 1 & Guru Kelas III & PNS & A \\
2 & Guru Kelas I & PNS & B \\
3 & Guru Kelas V & PNS & C \\
4 & Guru Kelas VI & PNS & D \\
5 & Guru Kelas IV & GTT & E \\
6 & Guru Kelas II & GTT & F \\
\hline
\end{tabular}

Teknik pengumpulan data dengan teknik non tes, yaitu observasi terhadap subjek penelitian. Dengan demikian, alat pengumpulan data adalah lembar pengamatan dan dokumen, baik dokumen foto kegiatan penelitian maupun dokumen administrasi dari subjek penelitian. Data penelitian berupa dokumen dan administrasi perencanaan pembelajaran dan kegiatan pembelajaran, dimana keduanya saling berhubungan. Sedangkan teknik analisis data adalah deskriptif komparatif pada data kuantitatif dan deskriptif kualitatif pada data kualitatif.

Tabel 2. Kriteria Penilaian

\begin{tabular}{ccc}
\hline Skor & Kriteria & Kategori \\
\hline $0-20$ & E & sangat rendah \\
$21-40$ & $\mathrm{D}$ & rendah \\
$41-60$ & $\mathrm{C}$ & cukup \\
$61-80$ & $\mathrm{~B}$ & tinggi \\
$81-100$ & $\mathrm{~A}$ & sangat tinggi \\
\hline
\end{tabular}

(Sumber: Arikunto, 2012)

Metode penilaian dalam penelitian ini yaitu: 1) rancangan pembelajaran (RPP); 2) pelaksanaan pembelajaran siklus I, terdiri dari membuka, proses, penutupan dan evaluasi sebelum dilakukan pembinaan TMQ; 3) pelaksanaan pembelajaran siklus II, setelah dilakukan pembinaan TMQ.

Terdapat 3 fase dalam pelaksanaan TQM ini, yaitu: 1) fase persiapan, yitu menyusun tim dan membentuk tujuan yang akan dicapai; 2) fase perencanaan, menyiapkan instrument penilaian, mengguakan metode PDCA (Plan-Do-Chek-Act). Plan adalah penentuan proses yang mana yang perlu diperbaiki, menentukan perbaikan apa yang dipilih dan menentukan data dan informasi 
Jenius: Jurnal of Education Policy and Elementary Education Issues

Vol.1, No.2, Desember 2020, pp. 63-73

yang diperlukan untuk perbaikan proses. Do adalah pengumpulan data dasar tentang jalannya proses, implementasi perubahan yang dikehendaki (skala kecil) dan mengumpulkan data untuk mengetahui perubahan (ada perbaikan atau tidak). Check adalah langkah pemimpin untuk menafsirkan hasil implementasi (berhasil atau tidak) atau upaya kepala sekolah untuk memperoleh pengetahuan baru tentang proses yang berada dalam tanggung jawabnya. Act adalah pengambilan keputusan perubahan mana yang akan diimplementasikan, pelatihan ulang bagi guru terkait dan pemantauan secara kontinyu; 3) fase pelaksanaan memberikan bimbingan kepada setiap tim dan mengaktifkan mereka, menggunakan metode PDCA (Plan-Do-Chek-Act).

\section{HASIL DAN PEMBAHASAN}

Kondisi awal pada penelitian ini, kineja guru masih jauh dari yang diharapkan. Dari 6 Guru Kelas yang ada, hanya 1 orang guru yang RPP-nya termasuk baik (B) dan juga hanya 1 orang (17\%) yang mengajarnya termasuk baik (B). Berikut ini analisis data kinerja guru dilihat dari pemantauan rencana pembelajaran dan pelaksanaan pembelajaran:

Tabel 3. Analisis Data Pemantauan Rencana Pelaksanaan Pembelajaran (RPP) pada Kondisi Awal.

\begin{tabular}{ccccc}
\hline No & Kode Guru & Skor & Nilai & Kriteria \\
\hline 1 & A & 45 & 50 & C \\
2 & B & 53 & 60 & C \\
3 & C & 65 & 72 & B \\
4 & D & 40 & 44 & C \\
5 & E & 42 & 46 & C \\
6 & F & 52 & 58 & C \\
\hline
\end{tabular}

Tabel 4. Analisis Data Pengamatan Kegiatan Pembelajaran pada Kondisi Awal.

\begin{tabular}{ccccc}
\hline No & Kode Guru & Skor & Nilai & Kriteria \\
\hline 1 & A & 41 & 48 & C \\
2 & B & 45 & 53 & C \\
3 & C & 49 & 58 & C \\
4 & D & 43 & 51 & C \\
5 & E & 41 & 48 & C \\
6 & F & 65 & 76 & B \\
\hline
\end{tabular}

Sesuai dengan analisis data pada tabel di atas, kinerja guru dalam perencanaan pembelajaran dengan nilai rata-rata sebesar 55 dimana 83\% termasuk kriteria cukup (C) dan kinerja guru dalam kegiatan pembelajaran dengan nilai rata-rata sebesar 56 dimana 83\% termasuk kriteria $\operatorname{cukup}(\mathrm{C})$. 
Jenius: Jurnal of Education Policy and Elementary Education Issues

Vol.1, No.2, Desember 2020, pp. 63-73

Tindakan pada Siklus I adalah sosialisasi dan diskusi tentang TQM. Pemahaman TQM menurut sudut pandang Guru. Hasilnya diimplementasikan dalam rencana pembelajaran dan pembelajaran. Sesuai dengan tindakan pada Siklus I, berikut ini analisis data kinerja guru dilihat dari pemantauan rencana pembelajaran dan pelaksanaan pembelajaran:

Tabel 5. Analisis Data Pemantauan Rencana Pelaksanaan Pembelajaran pada Siklus I.

\begin{tabular}{ccccc}
\hline No & Kode Guru & Skor & Nilai & Kriteria \\
\hline 1 & A & 61 & 68 & B \\
2 & B & 70 & 78 & B \\
3 & C & 73 & 81 & A \\
4 & D & 60 & 66 & B \\
5 & E & 53 & 58 & B \\
6 & F & 70 & 78 & B \\
\hline
\end{tabular}

Tabel 6. Analisis Data Pengamatan Kegiatan Pembelajaran pada Siklus I.

\begin{tabular}{ccccc}
\hline No & Kode Guru & Skor & Nilai & Kriteria \\
\hline 1 & A & 50 & 59 & C \\
2 & B & 50 & 59 & C \\
3 & C & 55 & 65 & B \\
4 & D & 64 & 75 & B \\
5 & E & 58 & 68 & B \\
6 & F & 72 & 85 & A \\
\hline
\end{tabular}

Sesuai dengan analisis data pada tabel di atas, kinerja guru dalam perencanaan pembelajaran dengan nilai rata-rata sebesar 72 dimana 83\% termasuk kriteria baik (B) dan kinerja guru dalam kegiatan pembelajaran dengan nilai rata-rata sebesar 69 dimana 33\% termasuk kriteria cukup (C), 50\% termasuk kriteria baik (B) dan 17\% termasuk kriteria sangat baik (A).

Tindakan pada Siklus II adalah bimbingan tentang TQM. Pemahaman TQM menurut sudut pandang Kepala Sekolah dan Guru. Hasilnya diimplementasikan dalam rencana pembelajaran dan pembelajaran. Sesuai dengan tindakan pada Siklus II, berikut ini analisis data kinerja guru dilihat dari pemantauan rencana pembelajaran dan pelaksanaan pembelajaran:

Tabel 7. Analisis Data Pemantauan Rencana Pelaksanaan Pembelajaran pada Siklus II.

\begin{tabular}{ccccc}
\hline No & Kode Guru & Skor & Nilai & Kriteria \\
\hline 1 & A & 68 & 76 & B \\
2 & B & 64 & 74 & B \\
3 & C & 80 & 89 & A \\
4 & D & 74 & 82 & A \\
5 & E & 63 & 70 & B \\
6 & F & 77 & 85 & A \\
\hline
\end{tabular}


Jenius: Jurnal of Education Policy and Elementary Education Issues

Vol.1, No.2, Desember 2020, pp. 63-73

Tabel 8. Analisis Data Pengamatan Kegiatan Pembelajaran pada Siklus II.

\begin{tabular}{ccccc}
\hline No & Kode Guru & Skor & Nilai & Kriteria \\
\hline 1 & A & 65 & 76 & B \\
2 & B & 66 & 78 & B \\
3 & C & 73 & 86 & A \\
4 & D & 76 & 89 & A \\
5 & E & 76 & 89 & A \\
6 & F & 75 & 88 & A \\
\hline
\end{tabular}

Sesuai dengan analisis data pada tabel di atas, kinerja guru dalam perencanaan pembelajaran dengan nilai rata-rata sebesar 79 dimana 50\% termasuk kriteria baik (B) dan 50\% termasuk kriteria sangat baik (A) dan kinerja guru dalam kegiatan pembelajaran dengan nilai ratarata sebesar 84 dimana 33\% termasuk kriteria baik (B) dan 67\% termasuk kriteria sangat baik (A).

Data kondisi awal, guru-guru SD Negeri Panohan dapat dikatakan kinerjanya masih rendah. Hal ini dapat dilihat dari 6 Guru Kelas yang ada, hanya 1 orang yang mampu menyusun RPP sebagai perencanaan pembelajaran yang termasuk kriteria baik (B). Dalam melaksanakan pembelajaran di kelas juga hanya 1 orang yang mengajarnya termasuk kriteria baik (B). Menariknya, guru yang baik dalam membuat perencanaan pembelajaran belum mampu melaksanakan pembelajaran dengan baik. Demikian sebaliknya, guru dengan perencanaan pembelajaran biasa-biasa saja, tetapi mampu melaksanakan pembelajaran dengan baik. Hal ini sesuai dengan analisis data pada Tabel 2 (Guru C dengan kriteria B) dan Tabel 3 (Guru F dengan kriteria B). Sedangkan guru lainnya dengan kinerja yang sama dalam membuat perencanaan pembelajaran dan melaksanakan pembelajaran.

Siklus I peneliti ini, menerapkan TQM secara teoritis, yaitu sosialisasi dan diskusi tentang TQM dalam kelompok, sehingga guru mempunyai pemahaman terhadap TQM. Kemudian hasilnya diimplementasikan dalam membuat perencanaan pembelajaran dan melaksanakan pembelajaran. Perencanaan pembelajaran yang termasuk kriteria baik (B) mencapai 100\%. Namun dalam pelaksanaan pembelajaran masih beragam, yaitu 33\% termasuk kriteria cukup (C), 50\% termasuk kriteria baik (B) dan 17\% termasuk kriteria sangat baik (A). Secara keseluruhan, kinerja guru mengalami peningkatan, sehingga termasuk kriteria baik (B).

Siklus II peneliti ini, menerapkan TQM dengan bimbingan individual, yaitu pembinaan tentang TQM secara individual, sehingga guru mencapai ketepatan yang tinggi dalam menerapkan Metode PDCA. Secara keseluruhan, kinerja guru semakin meningkat, baik dalam perencanaan maupun pelaksanaan pembelajaran. Nilai rata-rata dalam perencanaan pembelajaran sebesar 79 dengan rincaian yang termasuk kriteria baik (B) mencapai 50\% dan kriteria sangat baik (A) 
Jenius: Jurnal of Education Policy and Elementary Education Issues

Vol.1, No.2, Desember 2020, pp. 63-73

mencapai 50\%. Dalam pelaksanaan pembelajaran termasuk kriteria sangat baik (A) dengan nilai rata-rata sebesar 84 dan rincian yang termasuk kriteria baik (B) mencapai 33\% dan kriteria sangat baik (A) mencapai 67\%. Secara keseluruhan, kinerja guru mengalami peningkatan, baik dalam membuat perencanaan pembelajaran maupun melaksanakan pembelajaran. Peningkatan kinerja guru dalam pembelajaran dapat dilihat pada tabel 8 berikut ini:

Tabel 9. Analisis Perbandingan Data Kinerja Guru pada Kondisi Awal, Siklus I dan Siklus II.

\begin{tabular}{cccccccc}
\multirow{2}{*}{ No } & \multirow{2}{*}{ Kode } & \multicolumn{2}{c}{ Perencanaan Pembelajaran } & \multicolumn{3}{c}{ Pelaksanaan Pembelajaran } \\
\cline { 3 - 7 } & & K. Awal & Siklus I & Siklus II & K. Awal & Siklus I & Siklus II \\
\hline 1 & A & $50(\mathrm{C})$ & $68(\mathrm{~B})$ & $76(\mathrm{~B})$ & $48(\mathrm{C})$ & $59(\mathrm{C})$ & $76(\mathrm{~B})$ \\
2 & $\mathrm{~B}$ & $60(\mathrm{C})$ & $78(\mathrm{~B})$ & $74(\mathrm{~B})$ & $53(\mathrm{C})$ & $59(\mathrm{C})$ & $78(\mathrm{~B})$ \\
3 & $\mathrm{C}$ & $72(\mathrm{~B})$ & $81(\mathrm{~A})$ & $89(\mathrm{~A})$ & $58(\mathrm{C})$ & $65(\mathrm{~B})$ & $86(\mathrm{~A})$ \\
4 & $\mathrm{D}$ & $44(\mathrm{C})$ & $66(\mathrm{~B})$ & $82(\mathrm{~A})$ & $51(\mathrm{C})$ & $75(\mathrm{~B})$ & $89(\mathrm{~A})$ \\
5 & E & $46(\mathrm{C})$ & $58(\mathrm{~B})$ & $70(\mathrm{~B})$ & $48(\mathrm{C})$ & $68(\mathrm{~B})$ & $89(\mathrm{~A})$ \\
6 & F & $58(\mathrm{C})$ & $78(\mathrm{~B})$ & $85(\mathrm{~A})$ & $76(\mathrm{~B})$ & $85(\mathrm{~A})$ & $88(\mathrm{~A})$ \\
\hline
\end{tabular}

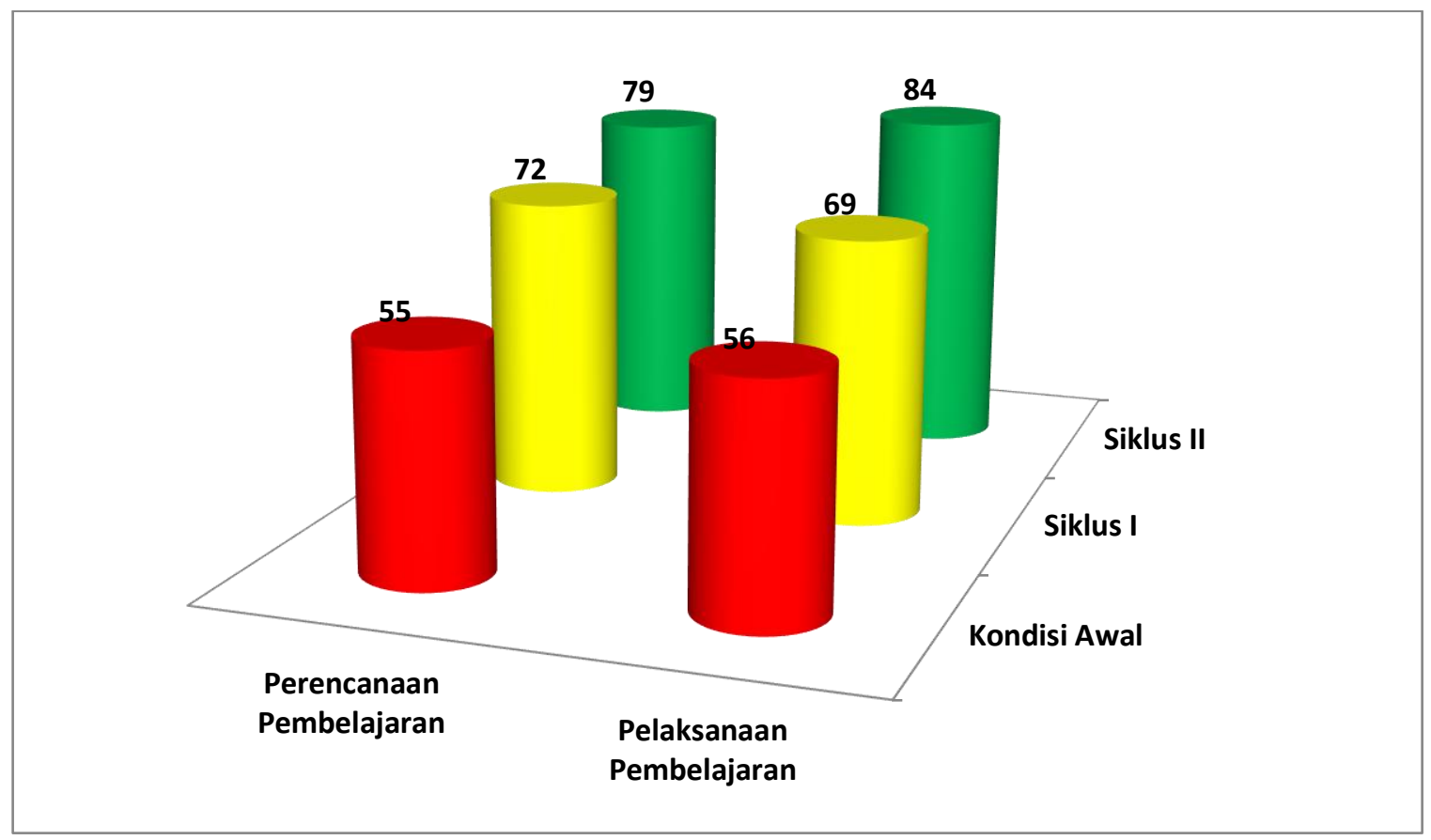

Grafik 1. Analisis Perbandingan Kinerja Guru pada Kondisi Awal, Siklus I dan Siklus II.

Sesuai dengan analisis data pada tabel dan grafik 1 di atas, kinerja guru dalam pembelajaran, baik dalam perencanaan maupun pelaksanaan pembelajaran mengalami peningkatan. Dalam hal perencanaan, kinerja meningkat dari nilai rata-rata sebesar 55 menjadi 72 pada Siklus I dan menjadi 79 pada Siklus II. Dalam hal pelaksanaan, kinerja meningkat dari nilai rata-rata sebesar 56 menjadi 69 pada Siklus I dan menjadi 84 pada Siklus II. Pada Siklus I, kinerja 
guru dalam membuat perencanaan pembelajaran adalah lebih baik daripada melaksanakan pembelajaran. Hal tersebut juga sesuai dengan tindakan yang fokus pada aspek teoritis dengan sosialisasi dan diskusi. Kinerja pada Siklus I mengalami peningkatan, namun belum memenuhi indikator kinerja. Sedangkan pada Siklus II, kinerja guru dalam melaksanakan pembelajaran adalah lebih baik daripada membuat perencanaan pembelajaran. Hal tersebut juga sesuai dengan tindakan yang fokus pada subjek penelitian dengan bimbingan secara individual. Kinerja pada Siklus II mengalami peningkatan secara optimal.

Peningkatan hasil telah terlihat pada Siklus I, persentase kinerja guru dalam perencanaan pembelajaran sudah memenuhi indikator kinerja, yaitu 83\% termasuk kriteria baik (B) dan 17\% termasuk kriteria sangat baik (A). Peningkatan tersebut lebih besar daripada indikator kinerja, yaitu 80\% termasuk kriteria baik (B). Namun demikian, peningkatan kinerja guru dalam pelaksanaan pembelajaran belum memenuhi indikator kinerja. Guru dengan kinerja yang termasuk kriteria baik (B) sebesar 50\% dan kriteria sangat baik (A) sebesar 17\% (secara keseluruhan sebesar 67\%), sehingga belum memenuhi indikator kinerja sebesar $80 \%$. Peningkatan tersebut benar-benar terpenuhi pada Siklus II dimana Guru dengan kinerja yang termasuk kriteria (B) sebesar 33\% dan kriteria sangat baik (A) sebesar 67\% (secara keseluruhan sebesar 100\%).

Menurut Pramesti \& Muhyadi (2018), faktor yang mempengaruhi kinerja guru adalah supervisi kepala sekolah, motivasi kerja, iklim kerja, status sosial ekonomi. Atas dasar ini pula, penulis melakukan tindakan kepada guru dengan penerapan TQM. Dalam penelitian ini adalah sosialisasi dan diskusi maupun bimbingan secara individual tentang TQM. Sesuai dengan tindakan tersebut, faktor lingkungan kerja mendukung kinerja guru. Hal tersebut sesuai dengan terpenuhinya indikator kinerja, bahkan pada Siklus I indikator yang berkaitan dengan nilai ratarata dalam perencanaan pembelajaran terpenuhi.

Peningkatan kinerja guru hasil setelah diterapkan TQM, membuktikan bahwa supervisi yang dilakukan kepala sekolah berpengaruh terhadap kinerja guru maupun keterampilan mengajarnya, hal ini sejalan dengan penelitian Supriono (2014) tentang kinerja guru se-tingkat SD dan sederajat dalam pembelajaran, meliputi perencanaan pembelajaran dengan menyusun RPP, pelaksanaan pembelajaran yang terdiri dari membuka, proses, penutupan dan evaluasi pembelajaran yang terdiri dari hasil-proses maupun KBM, termasuk baik. Hal tersebut sesuai dengan pengaruh dari supervisi akademik kepala sekolah. Artinya supervisi akademik kepala sekolah berpengaruh terhadap kinerja guru dalam pembelajaran. Pengaruh tersebut sebesar 79,2\% yang termasuk kategori tinggi. Hasil penelitian Saepudin (2012) tentang kinerja guru se-tingkat 
Jenius: Jurnal of Education Policy and Elementary Education Issues

Vol.1, No.2, Desember 2020, pp. 63-73

SMA dan sederajat dalam pembelajaran, meliputi perencanaan pembelajaran dengan menyusun RPP, pelaksanaan pembelajaran yang terdiri dari membuka, proses, penutupan dan evaluasi pembelajaran yang terdiri dari hasil-proses maupun KBM, termasuk baik. Hal tersebut sesuai dengan pengaruh dari supervisi akademik kepala sekolah. Artinya supervisi akademik kepala sekolah berpengaruh terhadap kinerja guru dalam pembelajaran. Pengaruh tersebut sebesar 79,2\% yang termasuk kategori tinggi. Sesuai dengan kedua hasi penelitian tersebut, maka kinerja guru dalam pembelajaran mengalami peningkatan sesuai dengan supervisi yang dilakukan oleh kepala sekolah, baik di tingkat SD dan sederajat maupun di tingkat SMA dan sederajat.

Sejalan dengan penelitian ini terdapat penelitian terdahulu yang menggunakan TQM sebagai metode peningkatan kualitas kinerja guru. Seperti yang dilakukan oleh Supeni (2014) yang meneliti peningkatan kinerja guru SMA/SMK di Kota Madiun dengan menggunakan TQM dan kedisiplinan, hasilnya apabila TQM dan kedisiplinan baik maka semakin baik kinerja guru SMA/ SMK di kota Madiun. Penelitian penerapan TQM pun telah dilakukan pada tingkat sekolah dasar oleh Marmoah, Suryanjani \& Fauziah (2019) di kecamatan Girimarto, dimana penelitian tersebut mendapatkan kesimpulan bahwa penerapan TQM pada pendidikan dasar dapat meningkatkan mutu pendidikan pada taraf yang sangat baik. Dalam penelitian terdapat peningkatan kinerja guru dalam pembelajaran, khususnya dalam perencanaan dan pelaksanaan pembelajaran. peningkatan tersebut bukan karena supervisi oleh kepala sekolah, tetapi penerapan TQM. Relevansi penelitian tersebut dengan penelitian ini adalah peningkatan kinerja guru dalam pembelajaran meningkat sesuai dengan supervisi maupun TQM oleh kepala sekolah.

\section{KESIMPULAN DAN SARAN}

\section{Simpulan}

Sesuai dengan hasil penelitian dan pembahasan, kesimpulan dalam penelitian ini adalah penerapan Total Quality Management (TQM) meningkatkan kinerja Guru Kelas SD Negeri Panohan, Kecamatan Gunem, Kabupaten Rembang pada Semester I tahun Pelajaran 2019/2020 dalam pembelajaran. Hal ini membuktikan bahwa TQM berpengaruh terhadap kinerja guru baik keterampilan dalam merancang pembelajaran, maupun keterampilan guru dalam mengajar yaitu membuka, proses, menutup dan mengevaluasi pembelajaran. 


\section{DAFTAR PUSTAKA}

Arikunto, S. (2012). Dasar-dasar evaluasi pendidikan. Jakarta: Bumi Aksara

Azizah, L., \& Witri, S. (2021). Peningkatan mutu pendidikan melalui penerapan total quality management dalam program akreditasi sekolah. Dawuh Guru: Jurnal Pendidikan MI/SD, 1(1), 69-78. doi: 10.35878/guru.v1i1.263.

Dewi, P. Y. A., \& Primayana, K. H. (2019). Peranan total quality management (TQM) di sekolah dasar. Jurnal Penjaminan Mutu, 5(2), 226-236. doi: 10.25078/jpm.v5i2.827.

Djamarah, S.B. (2000). Guru dan anak didik dalam interaksi edukatif. Jakarta: Rineka Cipta.

Handayani, M. W. R. (2014). Faktor-faktor yang mempengaruhi kinerja guru ipa (sains) smp negeri se-kecamatan ngaglik kabupaten sleman. Jurnal penelitian ilmu pendidikan, 7(2). doi: 10.21831/jpipfip.v7i2.4923.

Hasanah, N. (2015). Dampak kompetensi profesional guru dalam meningkatkan mutu pendidikan madrasah ibtidaiyah di kota Salatiga. INFERENSI: Jurnal Penelitian Sosial Keagamaan, 9(2), $445-466$.

Indana, N. (2017). Implementasi total quality management (TQM) dalam meningkatkan mutu pendidikan:(studi kasus di MTs Salafiyah Syafi'iyah Tebuireng). Al-Idaroh: Jurnal Studi Manajemen Pendidikan Islam, 1(1), 62-86.

Marmoah, S., Suryanjani, S., \& Fauziah, M. (2019). Implementasi total quality management (TQM) di pendidikan dasar. Perspektif Ilmu Pendidikan, 33(1), 41-50.. doi: org/10.21009/pip.331.5.

Masturi, M., Ramdani, A., \& Muntari, M. (2017). Pengaruh penerapan total quality management (TQM) dan budaya organisasi terhadap kinerja guru SMK negeri 3 Mataram. (JPAP) Jurnal Praktisi Administrasi Pendidikan, 2(2).

Pramesti, D., \& Muhyadi, M. (2018). Faktor-faktor yang mempengaruhi kinerja guru SMA. Harmoni Sosial: Jurnal Pendidikan IPS, 5(1), 43-56. doi: 10.21831/hsjpi.v5i1.11854.

Saepudin. (2012). Pengaruh supervisi akademik terhadap kinerja guru pada sma negeri guligas 2 sliyeg kabupaten indramayu (Tesis yang tidak dipublikasikan), Universitas Indonesia

Safitri, E., \& Sontani, U. T. (2016). Keterampilan mengajar guru dan motivasi belajar siswa sebagai determinan terhadap hasil belajar. Jurnal Pendidikan Manajemen Perkantoran (JPManper), 1(1), 144-153.

Saragih, A. H. (2008). Kompetensi minimal seorang guru dalam mengajar. Jurnal Tabularasa, 5(1), 23-34.

Supeni, B. S. (2014). Pengaruh total quality management (tqm) dan kedisiplinan guru terhadap kinerja guru sma/smk di kota madiun. Assets: Jurnal Akuntansi Dan Pendidikan, 3(2), 128. doi: 10.25273/jap.v3i2.1217.

Suponco, P. (2018). Kepemimpinan partisipatif kepala sekolah dan kompetensi guru serta pengaruhnya terhadap mutu pendidikan. Edum Journal, 1(2), 90-95. doi: 10.31943/edumjournal.v1i2.13.

Supriono, E. (2014). Pengaruh supervisi kepala sekolah terhadap kinerja guru SD se-Kecamatan Sewon, Bantul, Yogyakarta (Skripsi yang tidak dipublikasikan), Universitas Negeri Yogyakarta.

Susanto, B., \& Mattalatta, M. (2018). Pengaruh kepemimpinan kepala sekolah, iklim sekolah dan kompetensi guru terhadap mutu pendidikan di MTS kabupaten Jeneponto. YUME: Journal of Management, 1(2): 197-212. doi: 10.21831/jpv.v2i2.1028

Syafaruddin. (2002). Manajemen mutu terpadu dalam pendidikan. Jakarta: Grasindo.

Zazin, N. (2011). Gerakan menata mutu pendidikan: Teori dan Aplikasi. Yogyakarta: Ar-Ruzz Media. 